\title{
Production of Low-Enriched Uranium Nitride Kernels for TRISO Particle Irradiation Testing
}

Fuel Cycle Research \& Development Advanced Fuels Campaign

J. W. McMurray

C. M. Silva

G. W. Helmreich

T. J. Gerczak

J. A. Dyer

J. L. Collins

R. D. Hunt

T. B. Lindemer

K. A. Terrani

Approved for public release. Distribution is unlimited.

Prepared for

U. S. Department of Energy Office of Nuclear Energy 


\section{DISCLAIMER}

This information was prepared as an account of work sponsored by an agency of the U.S. Government. Neither the U.S. Government nor any agency thereof, nor any of their employees, makes any warranty,

expressed or implied, or assumes any legal liability or responsibility for the accuracy, completeness, or usefulness, of any information, apparatus, product, or process disclosed, or represents that its use would not infringe privately owned rights. References herein to any specific commercial product, process, or service by trade name, trade mark, manufacturer, or otherwise, does not necessarily constitute or imply its endorsement, recommendation, or favoring by the U.S. Government or any agency thereof. The views and opinions of authors expressed herein do not necessarily state or reflect those of the U.S. Government or any agency thereof. 
ORNL/SR-2016/268

Revision 0

\title{
Production of Low-Enriched Uranium Nitride Kernels for TRISO Particle Irradiation Testing
}

\author{
J. W. McMurray \\ C. M. Silva \\ G. W. Helmreich \\ T. J. Gerczak \\ J. A. Dyer \\ J. L. Collins \\ R. D. Hunt \\ T. B. Lindemer \\ K. A. Terrani
}

June 2016

Prepared by

OAK RIDGE NATIONAL LABORATORY

Oak Ridge, TN 37831-6283

managed by

UT-BATTELLE, LLC

for the

US DEPARTMENT OF ENERGY

under contract DE-AC05-00OR22725 

INTENTIONALLY BLANK 


\begin{abstract}
A large batch of UN microspheres to be used as kernels for TRISO particle fuel was produced using carbothermic reduction and nitriding of a sol-gel feedstock bearing tailored amounts of low-enriched uranium (LEU) oxide and carbon. The process parameters, established in a previous study, produced phasepure $\mathrm{NaCl}$ structure $\mathrm{UN}$ with dissolved $\mathrm{C}$ on the $\mathrm{N}$ sublattice. The composition, calculated by refinement of the lattice parameter from X-ray diffraction, was determined to be $\mathrm{UC}_{0.27} \mathrm{~N}_{0.73}$. The final accepted product weighed $197.4 \mathrm{~g}$. The microspheres had an average diameter of $797 \pm 1.35 \mu \mathrm{m}$ and a composite mean theoretical density of $89.9 \pm 0.5 \%$ for a solid solution of UC and UN with the same atomic ratio; both values are reported with their corresponding calculated standard error.
\end{abstract}


INTENTIONALLY BLANK 


\section{CONTENTS}

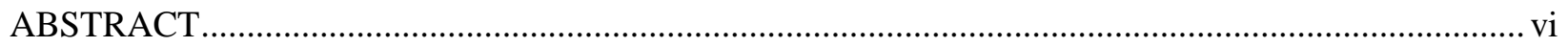

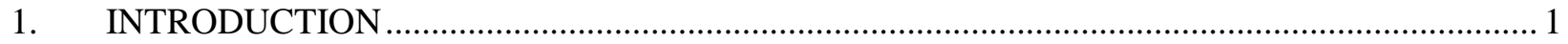

2. OVERALL FCM TRISO PROCESS DESCRIPTION ….......................................................... 2

3. LOW-ENRICHED URANIUM NITRIDE FABRICATION PROCESS …................................... 3

4. CHARACTERIZATION OF FINAL PRODUCT UN MICROSPHERES ................................... 6

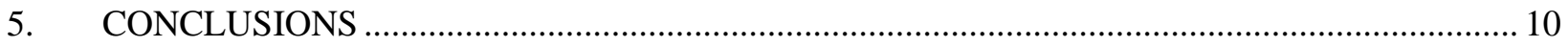

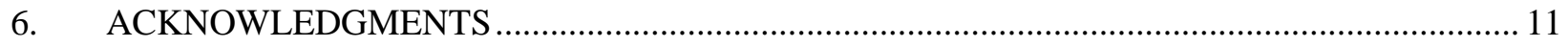

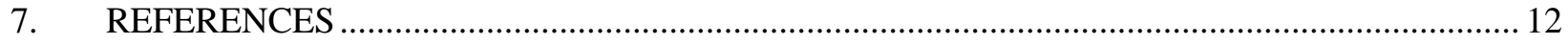




\section{FIGURES}

Figure $\quad$ Page

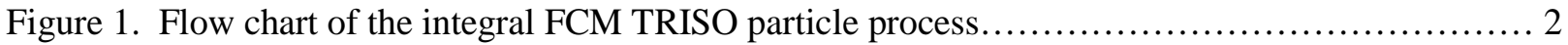

Figure 2. Cross-sectioned FCM TRISO particle resulting from process variables from early kernel

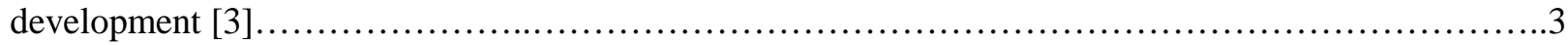

Figure 3. Flow diagram for the internal gelation sol-gel feedstock $\ldots \ldots \ldots \ldots \ldots \ldots \ldots \ldots \ldots \ldots \ldots \ldots \ldots \ldots$

Figure 4. Process used to convert the sol-gel feedstock to $\sim 800 \mu \mathrm{m}$ and $89.9 \%$ TD phase-pure $\mathrm{UC}_{\mathrm{x}} \mathrm{N}_{1-\mathrm{x}}$ microspheres with 13.5 at. \% dissolved C. Note that reference [3] gives $\sim 1950^{\circ} \mathrm{C}$ for isothermal hold but $1900^{\circ} \mathrm{C}$ was used for this work for consistency with the majority of previous DU exploratory batches.....5

Figure 5. Engineering drawings of the W crucible used for the conversion step of UN microsphere

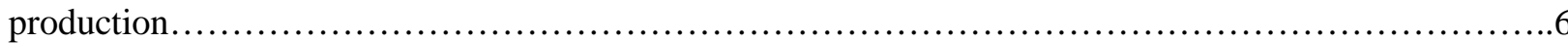

Figure 6. Kernel mass distribution as a function of average diameter. The \%TD with associated standard errors are given for the microspheres that fell within a specified size range.......................... 7

Figure 7. XRD pattern for a representative specimen taken from the final product......................8

Figure 8. Computed phase relations in the U-C-N system at (a) $300^{\circ} \mathrm{C}$, (b) $800^{\circ} \mathrm{C}$, (c) $1400^{\circ} \mathrm{C}$, and (d)

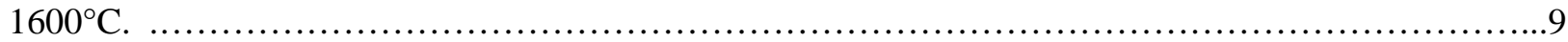

Figure 9. SEM images (a,b) showing the pore structure in a kernel from the final product $\mathrm{UC}_{0.27} \mathrm{~N}_{0.73}$. The optical microscope images in (c) and (d) show what appears to be mostly high density microspheres. 


\section{TABLES}

Table

Page

Table 1. Impurity limits for the process gases used for the sol-gel feedstock to UN conversions..........5

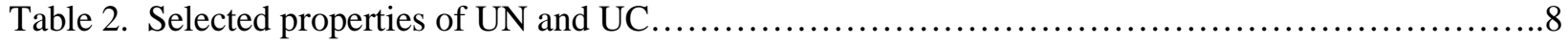




\section{Production of Low Enriched Uranium Nitride Kernels for TRISO Particle Irradiation Testing}

\section{INTRODUCTION}

The fully ceramic microencapsulated (FCM) fuel form uses tri-structural isotropic (TRISO)-coated particles embedded in a dense SiC matrix. The FCM concept leverages existing Light Water Reactor (LWR) infrastructure with an Accident Tolerant (AT) drop-in replacement for conventional $\mathrm{UO}_{2}$. With an FCM compact, much of the $\mathrm{U}$ volume associated with traditional $\mathrm{UO}_{2}$ pellets has been replaced by TRISO coatings and the $\mathrm{SiC}$ matrix thus necessitating a higher fissile-density fuel, such as UN, to be used as the kernel of the TRISO particles. Thorough technical details can be found in previous publications [1, 2].

This work reports on the successful production of a large batch of UN TRISO particle fuel kernels using carbothermic reduction and nitriding of a sol-gel feedstock bearing tailored amounts of low enriched uranium (LEU) oxide and carbon. The process parameters were established by Lindemer et al. in a previous report [3]. The final product was phase-pure $\mathrm{NaCl}$ structure $\mathrm{UC}_{0.27} \mathrm{~N}_{0.73}$, weighed $197.4 \mathrm{~g}$, had an average diameter of $797 \pm 1.35 \mu \mathrm{m}$ and a composite theoretical density (TD) of $89.9 \pm 0.5 \%$ for a solid solution of UC and UN with the same atomic ratio (see Section 4). Each value is reported with a corresponding standard error. The microspheres will be coated with the appropriate TRISO layers using chemical vapor deposition and prepared for planned irradiation testing. 


\section{OVERALL FCM TRISO PROCESS DESCRIPTION}

The production of FCM TRISO particles can be subdivided into two distinct steps as shown in Figure 1. Feedstock $\mathrm{UO}_{3}+\mathrm{C}$ spheres produced using a sol-gel method are converted to $\mathrm{UC}_{\mathrm{x}} \mathrm{N}_{1-\mathrm{x}}$ by carbothermic reduction, occurring in two calcining steps governed by the reactions given in Equations 1 and 2, and subsequent nitriding that proceeds via Equation. 3.

$$
\begin{aligned}
& U O_{3}+C \rightarrow U O_{2}+1 / 2 C+1 / 2 C_{2} \\
& U O_{2}+(3-2 y) C \rightarrow U O_{y} C_{1-y}+(2-y) C O \\
& \left(\frac{1-2 y-x}{3-2 y}\right) U O_{2}+\left(\frac{2+x}{3-2 y}\right) U O_{y} C_{1-y}+\left(\frac{1-x}{2}\right) N_{2} \rightarrow U C_{x} N_{1-x}+\left(\frac{x y-2 y-2 x+2}{3-2 y}\right) C O
\end{aligned}
$$

The resulting $\mathrm{UC}_{\mathrm{x}} \mathrm{N}_{1-\mathrm{x}}$ kernels are coated with carbon buffer, inner pyrolytic carbon (IPyC), SiC, and an outer pyrolytic carbon (OPyC) layers using chemical vapor deposition (CVD) as has previously been done in extensive TRISO development work [4-6]. The CVD process is sensitive to the properties of the material to be coated (e.g. morphology, size, weight, density, etc.). As such, the coating parameters for FCM TRISO were established using depleted uranium (DU) bearing $\mathrm{UC}_{\mathrm{x}} \mathrm{N}_{1-\mathrm{x}}$ microspheres produced during the TRISO kernel research and development (R\&D) phase reported in [3]. Figure 2 shows a cross-sectioned final product FCM TRISO particle with a high density $\mathrm{UC}_{\mathrm{x}} \mathrm{N}_{1-\mathrm{x}}$ kernel.

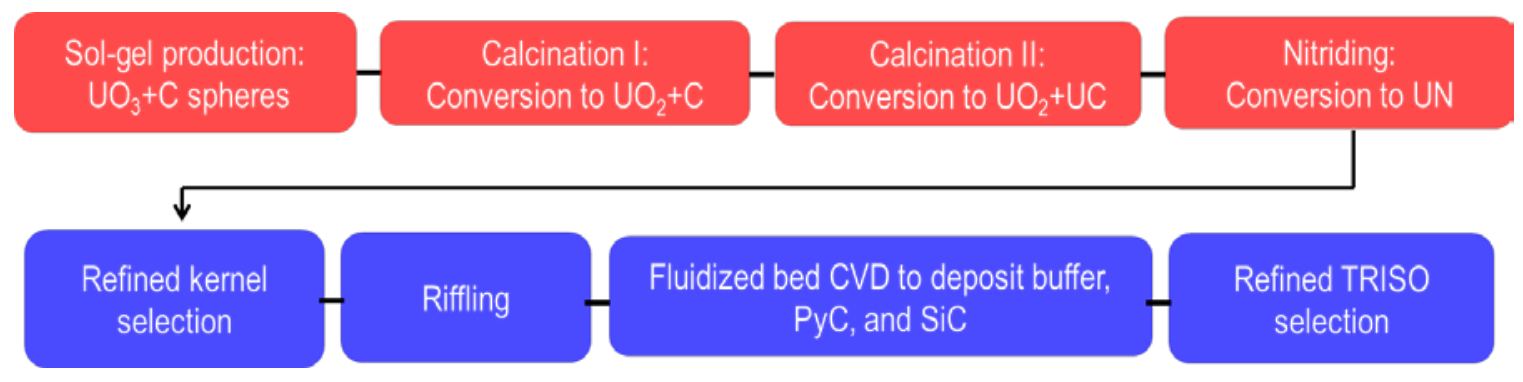

Figure 1. Flow chart of the integral FCM TRISO particle process. 


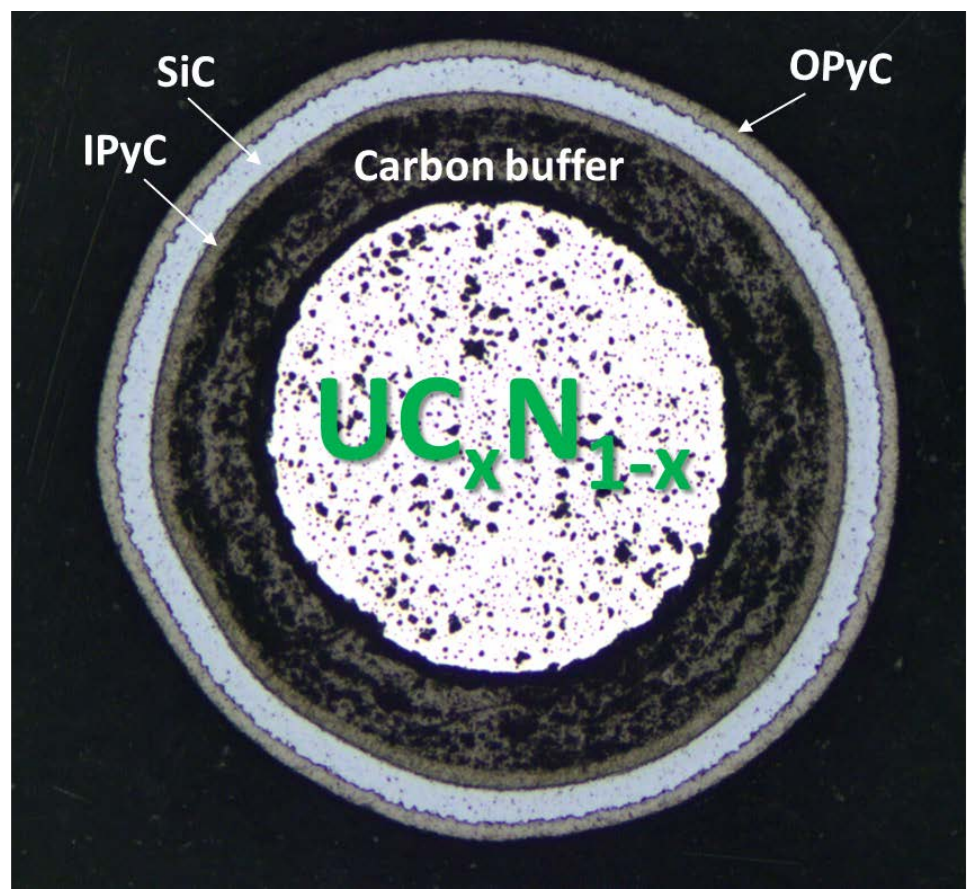

Figure 2. Cross-sectioned FCM TRISO particle resulting from process variables from early kernel development [3].

\section{LOW-ENRICHED URANIUM NITRIDE FABRICATION PROCESS}

The internal gelation process was used to produce 1400-2000- $\mu$ m-diameter spheres of hydrated $\mathrm{UO}_{3}$ with homogenously-embedded carbon powder. The starting material consisted of uranium oxides, with a ${ }^{235} \mathrm{U}$ enrichment of 7.35 at. \% U, and Cabot Mogul L carbon black; these components were dispersed throughout the gel spheres as described in ref. [7]. As pointed out in [3], this form of $\mathrm{C}$ tends to aggregate. This was mitigated by using the dispersing agent, Tamol SN, which was added to the chilled basic hexamethylenetetramine (HMTA)/urea solution and sonicated for 5 min with a Hielscher UP200S ultrasonic probe. Since sonification heats the solution, it was subsequently rechilled. To this, a chilled acid deficient uranyl nitrate solution was added to form the broth which was then added as droplets in a controlled fashion into a flowing stream of hot $\left(\sim 62^{\circ} \mathrm{C}\right)$ immiscible silicone oil to facilitate the gelation reaction. The gelled spheres were then washed and dried resulting in a product with a $\mathrm{C} / \mathrm{U}$ ratio of 2.65 with $\sim 2$ moles of adsorbed $\mathrm{H}_{2} \mathrm{O}$ /mole $\mathrm{U}$ and traces of $\mathrm{NH}_{3}$. A flow diagram of the process is shown in Figure 3. 


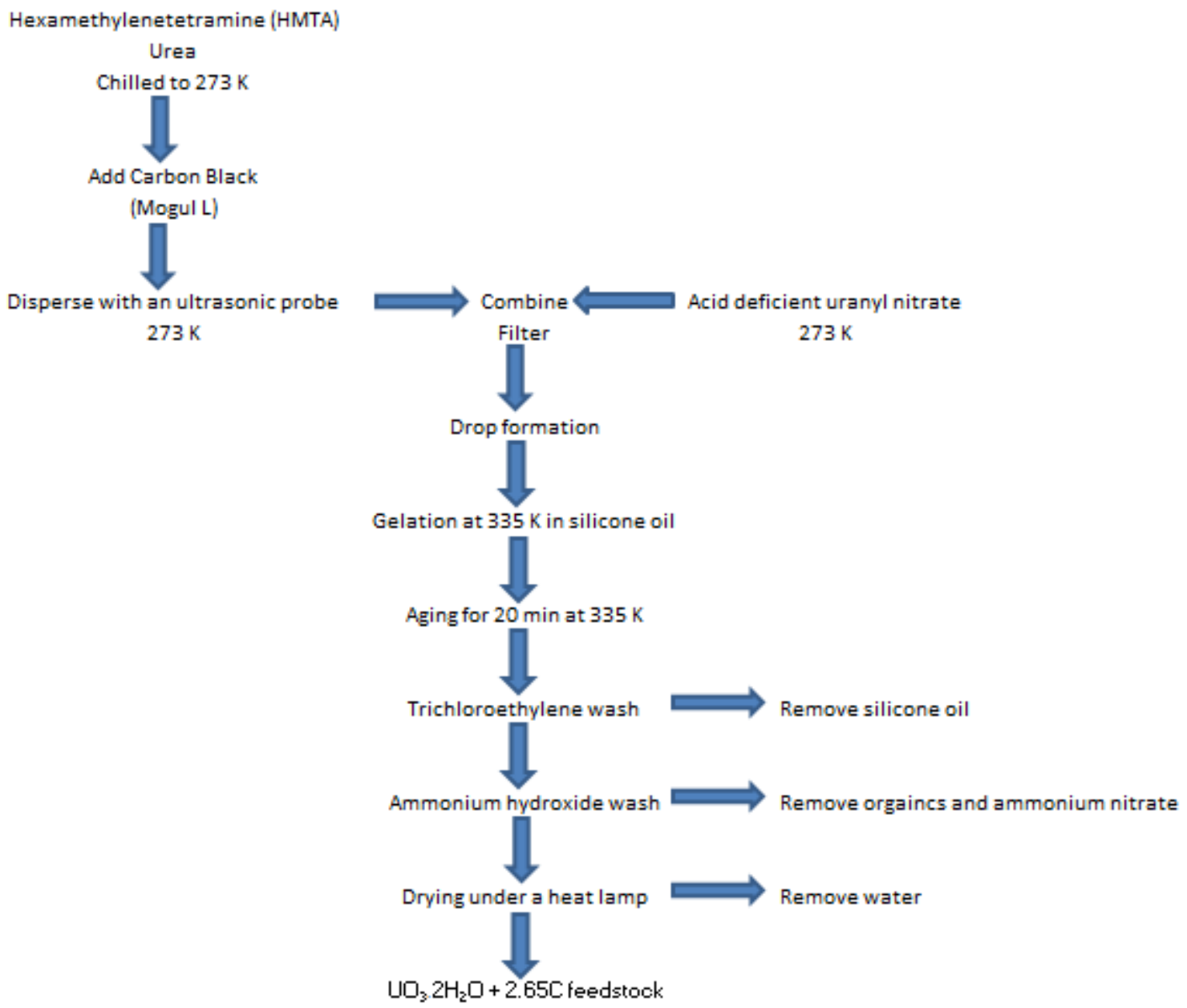

Figure 3. Flow diagram for the internal gelation sol-gel feedstock.

This material weighed $468 \mathrm{~g}$ and was used as a feedstock to produce five independent batches totaling 197.4 g of phase-pure UN microspheres with a diameter of 750-870 $\mu \mathrm{m}$ and an average geometric TD of $89.9 \pm 0.5 \%$. Figure 4 depicts the overall conversion process using the parameters determined in [3]. 


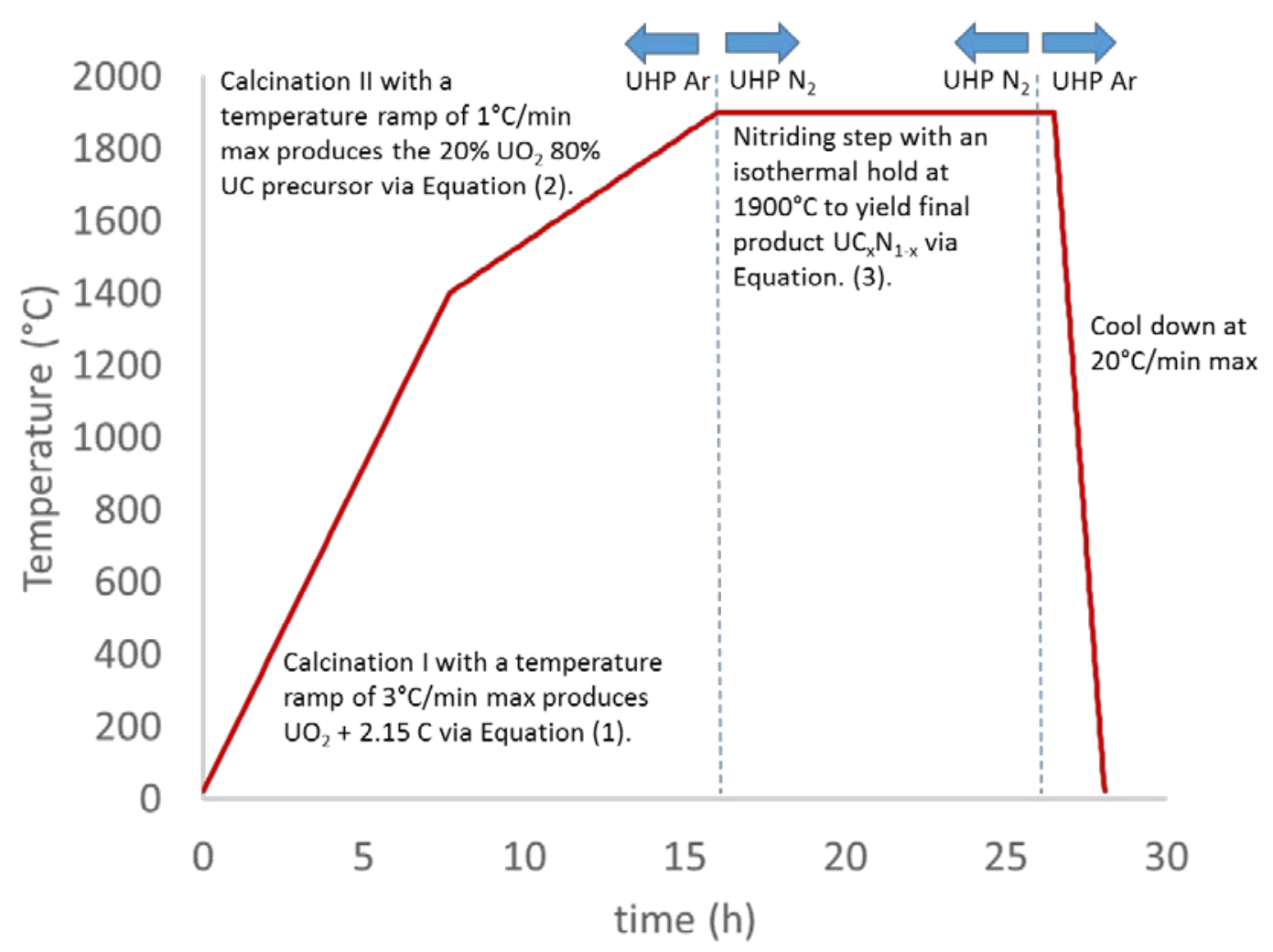

Figure 4. Process used to convert the sol-gel feedstock to $\sim 800 \mu \mathrm{m}$ and $89.9 \%$ TD phase-pure $\mathrm{UC}_{\mathrm{x}} \mathrm{N}_{1-\mathrm{x}}$ microspheres with 13.5 at. \% dissolved C. Note that reference [3] gives $\sim 1950^{\circ} \mathrm{C}$ for isothermal hold but $1900^{\circ} \mathrm{C}$ was used for this work for consistency with the majority of previous DU exploratory batches.

All gases were Air Liquide Ultra High Purity (UHP) grade with nominal impurity limits shown in Table 1. The conversion took place in an Astro furnace (Thermal Technology, LLC) with a graphite heating element capable of reaching $2200{ }^{\circ} \mathrm{C}$. The reaction chamber consisted of a hollow W cylinder (Figure 5) whereby process gas was introduced by continuous flow through the $\mathrm{W}$ tube shown in Figure 5(a), entering at the orifice in Figure 5(b), and exited at the opening in the gravity sealed lid, Figure 5(c). The feedstock material was positioned above a 60 -inch by 60 -inch-mesh $\mathrm{W}$ screen with a wire diameter of 0.004 inches and an opening of 0.0127 inches. This was done in order to separate the spheres from the inlet of the chamber for containment while still allowing for intimate contact with the process gas.

Table 1. Impurity limits for the process gases used for the sol-gel feedstock to UN conversions.

\begin{tabular}{ccc}
\hline Impurity & UHP Ar & UHP N \\
\hline Moisture & $<3 \mathrm{ppm}$ & $<3 \mathrm{ppm}$ \\
\hline $\mathrm{O}_{2}$ & $<2 \mathrm{ppm}$ & $<2 \mathrm{ppm}$ \\
\hline Hydrocarbons & $<0.5 \mathrm{ppm}$ & $<0.5 \mathrm{ppm}$ \\
\hline $\mathrm{CO}_{2}$ & $<1 \mathrm{ppm}$ & $<1 \mathrm{ppm}$ \\
\hline $\mathrm{CO}$ & $<0.5 \mathrm{ppm}$ & $<1 \mathrm{ppm}$ \\
\hline $\mathrm{N}_{2}$ & $<5 \mathrm{ppm}$ & \\
\hline
\end{tabular}




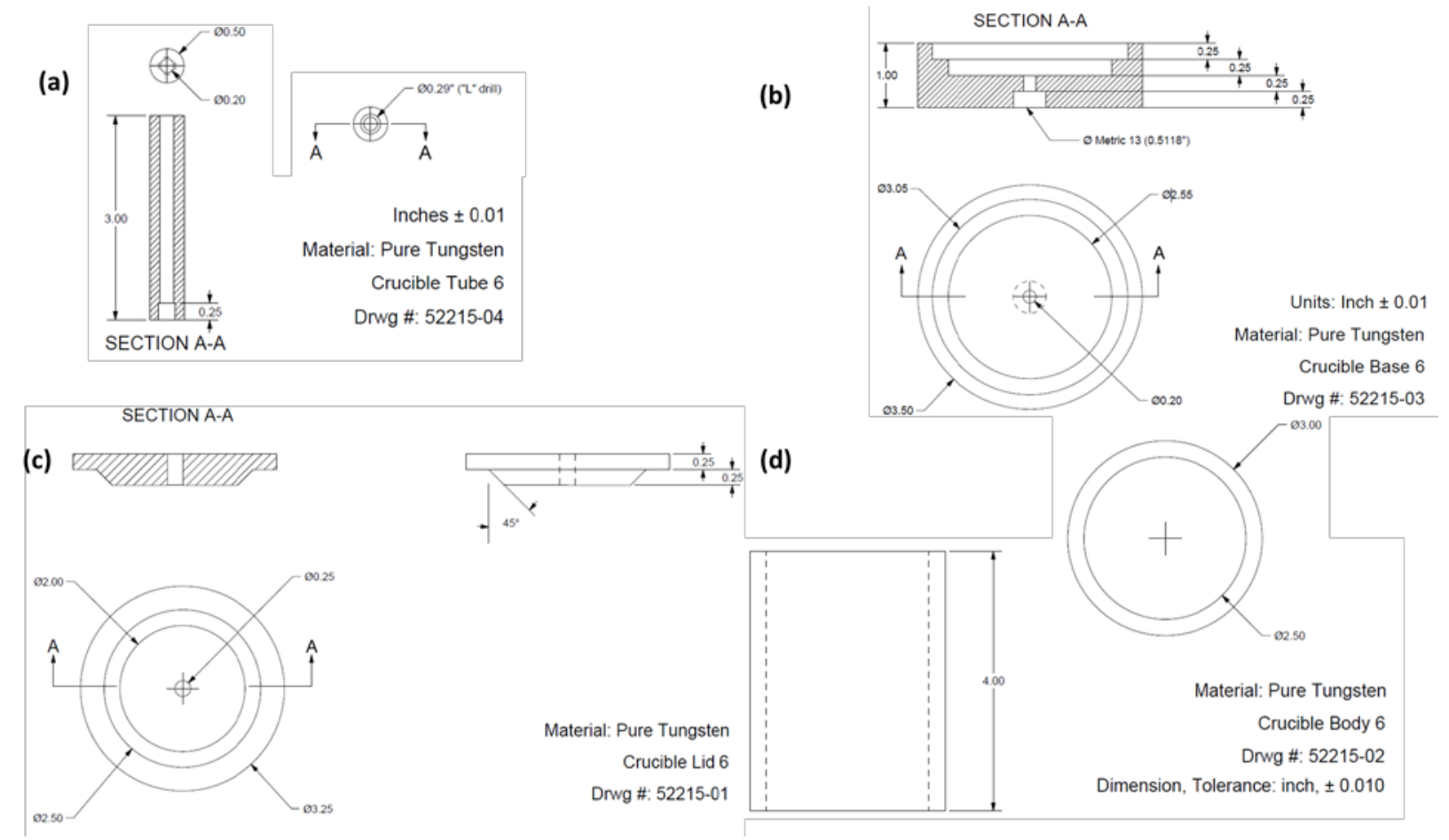

Figure 5. Engineering drawings of the $\mathrm{W}$ crucible used for the conversion step of UN microsphere production.

\section{CHARACTERIZATION OF FINAL PRODUCT UN MICROSPHERES}

The product, or batches, from each carbothermic and nitriding conversion run were upgraded by handtabling to remove non-spherical kernels, followed by roller micrometer division into eleven bins based on diameter. Each bin was configured to retain kernels within a 25 $\mu \mathrm{m}$ diameter range, and material with diameters between 750-850 $\mu \mathrm{m}$ was set aside to be composited into the final product. A subset from each bin was characterized by determination of average particle weight and diameter using established procedures from the Advanced Gas Reactor program detailed in references [3, 8]. Given the assumption of spherical particles, this data was used to estimate average density for each bin, as shown in Figure 6. The TD was calculated relative to a $27 \%$ UC-73\% UN solid solution.

A final upgrading step was applied to each batch of material before compositing. Kernels were spread into a monolayer and visually surveyed to remove those that were oblong but yet round enough to pass the earlier hand-tabling. Next, material from all five batches was combined and riffled into sub-lots for characterization and coating charges. The composite average kernel diameter and density, reported here with their standard error, were found to be $797 \pm 1.35 \mu \mathrm{m}$ and $12.67 \pm 0.07 \mathrm{~g} / \mathrm{cm}^{3}$ respectively. The calculated $100 \%$ TD for $\mathrm{UC}_{0.27} \mathrm{~N}_{0.73}$ is $14.1 \mathrm{~g} / \mathrm{cm}^{3}$; therefore, the final accepted product was determined to be $89.9 \pm 0.5 \%$ TD. The median size and mean TD distribution by weight are shown in Figure 6 . The phase purity and chemical composition of the final product were determined with powder X-ray diffractometry (XRD) as was done in [3]. 


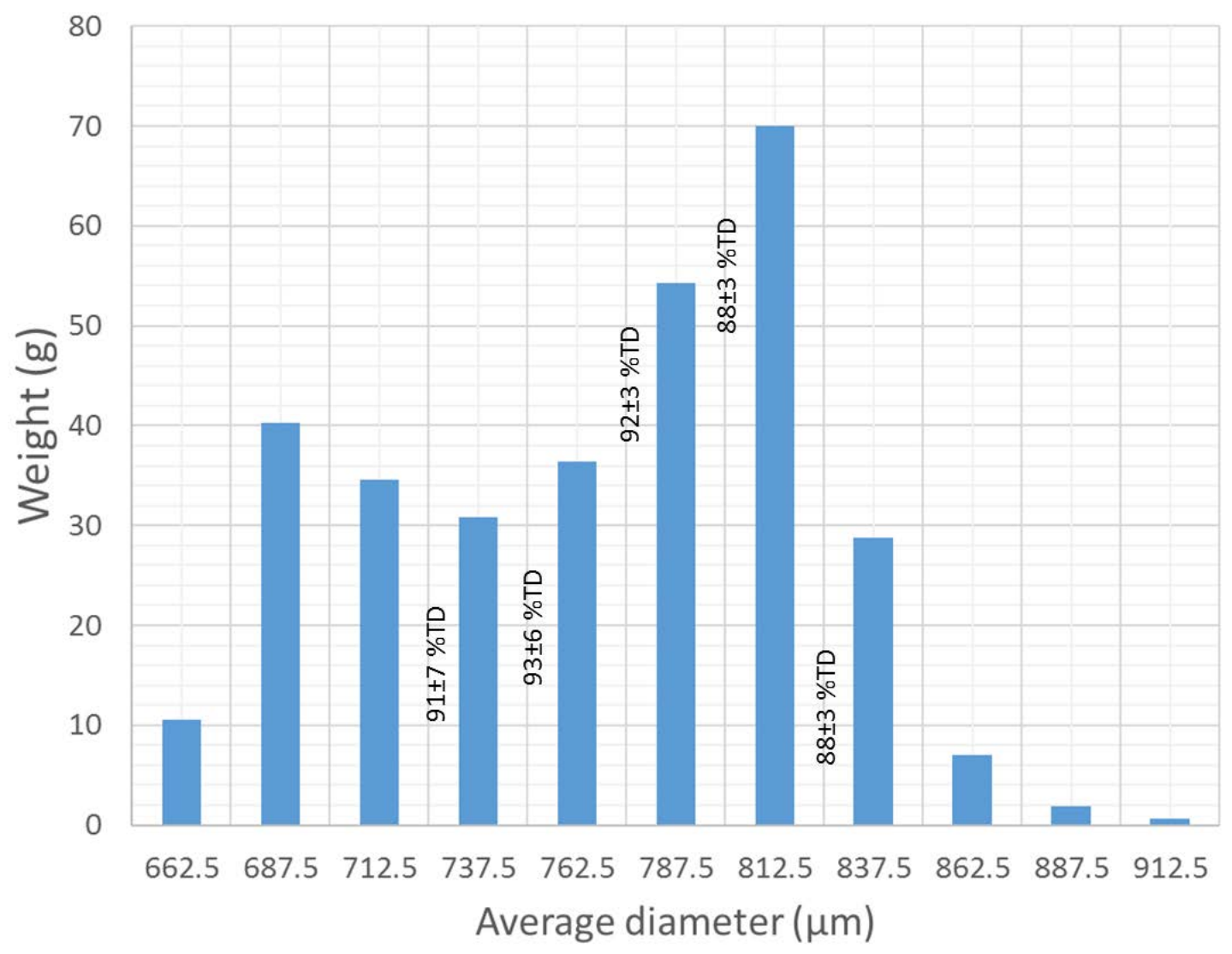

Figure 6. Kernel mass distribution as a function of average diameter. The \%TD with associated standard errors are given for the microspheres that fell within a specified size range.

The XRD pattern in Figure 7 indicates the final product is phase-pure $\mathrm{NaCl}$ structure $\mathrm{UC}_{\mathrm{x}} \mathrm{N}_{1-\mathrm{x}}$. The refined lattice parameter (4.9125 $\pm 0.0001 \AA$ ) suggests a composition corresponding to $\mathrm{UC}_{0.27} \mathrm{~N}_{0.73}$. If desired, in [3] it was demonstrated that the $\mathrm{N}$ content can be increased by additional processing in flowing $\mathrm{N}_{2}-4 \% \mathrm{H}_{2}$ via removal of the solid-solution $\mathrm{C}$ as $\mathrm{HCN}$ and substituting $\mathrm{N}$ for it on the anion sublattice. As mentioned in Section 2, the integral FCM TRISO fabrication involves coating the kernels using CVD, which required considerable $\mathrm{R} \& \mathrm{D}$ to determine parameters that produced acceptable results. Therefore, the $\mathrm{N}$ enrichment step with $\mathrm{N}_{2}-4 \% \mathrm{H}_{2}$ was not used in order to preserve the CVD process developed for depleted U-bearing $\mathrm{UC}_{\mathrm{x}} \mathrm{N}_{1-\mathrm{x}}$ of comparable compositions. 


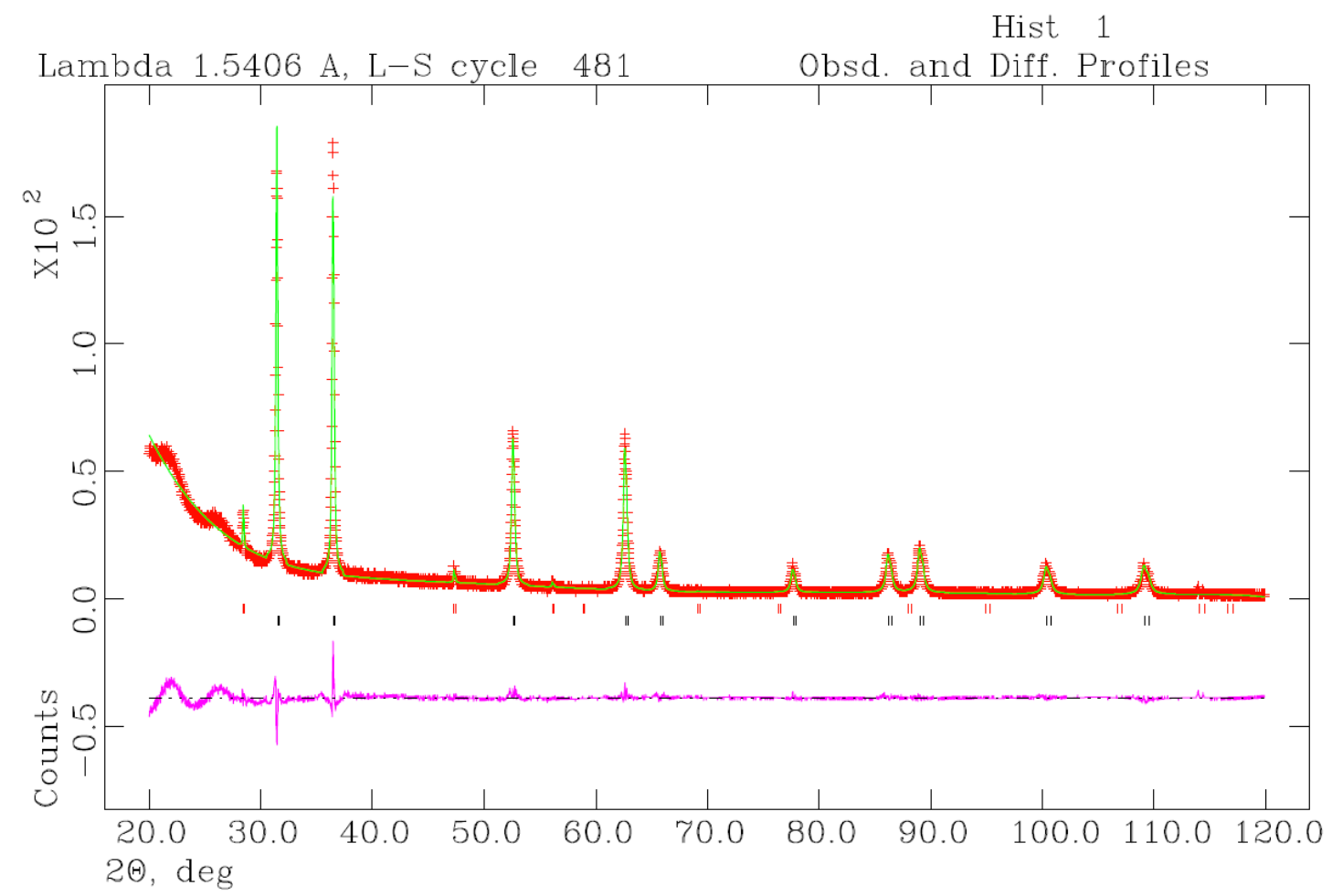

Figure 7. XRD pattern for a representative specimen taken from the final product.

Uranium monocarbide is isostructural with UN exhibiting complete miscibility over an extensive temperature range with comparable physical properties summarized in Table 2 from [9]. In the presence of excess C, i.e., the buffer layer in a TRISO particle, $\mathrm{UC}_{\mathrm{x}} \mathrm{N}_{1-\mathrm{x}}$ and graphite coexist up to $\mathrm{x}$ values of $\sim 0.89$ and 0.83 for 800 and $1400^{\circ} \mathrm{C}$, respectively, as illustrated in Figure 8. The significance of this is that a deleterious second phase precipitate, i.e. $\mathrm{UC}_{2}$ or $\mathrm{U}_{2} \mathrm{C}_{3}$, is not expected under anticipated operation temperatures, departures thereof associated with accident scenarios, or during the CVD TRISO coating that uses temperatures within the range covered in Figure 8. Due to the similar properties of UC and UN, UN with $27 \% \mathrm{C}$ on the anion sublattice is considered to be acceptable.

Table 2. Selected properties of UN and UC.

\begin{tabular}{lcc}
\hline \multicolumn{1}{c}{ Property } & UN & UC \\
\hline Molecular mass, amu & 252 & 250 \\
\hline Density, g/cm ${ }^{3}$ & 14.3 & 13.63 \\
\hline Melting point, ${ }^{\circ} \mathrm{C}$ & 2850 & 2365 \\
\hline Heat capacity, $\mathrm{J} /(\mathrm{mol} \cdot \mathrm{K})$ & 48 & 50 \\
\hline Thermal conductivity, $\mathrm{W} /(\mathrm{m} \cdot \mathrm{K})$ & 13 & 25.3 \\
\hline Linear expansion coefficient, $1 / \mathrm{K}$ & $7.52 \times 10^{-6}$ & $10.1 \times 10^{-6}$ \\
\hline Electrical resistivity, $\Omega \cdot \mathrm{m}$ & $1.46 \times 10^{-6}$ & $727.7 \times 10^{-8}$ \\
\hline
\end{tabular}



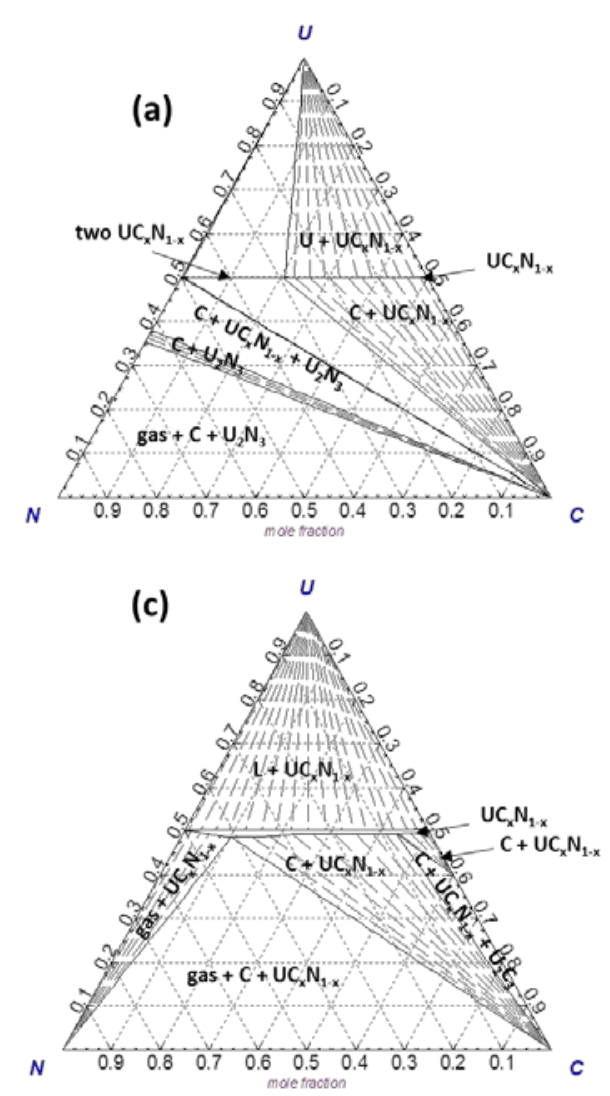
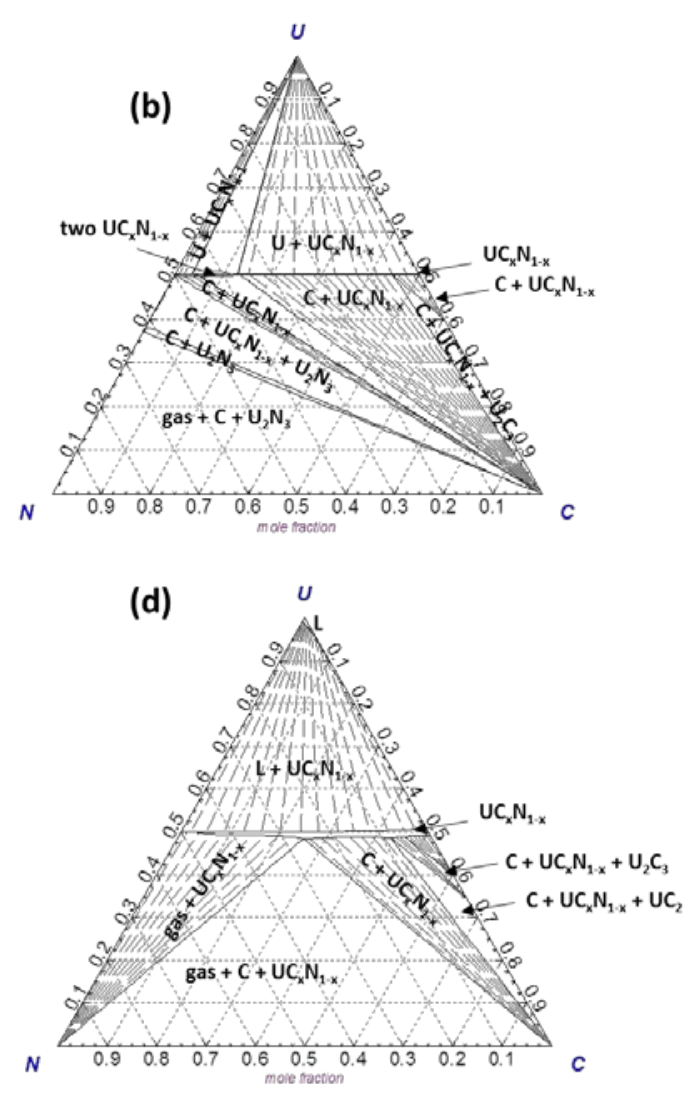

Figure 8. Computed phase relations in the U-C-N system at (a) $300^{\circ} \mathrm{C}$, (b) $800^{\circ} \mathrm{C}$, (c) $1400^{\circ} \mathrm{C}$, and (d) $1600^{\circ} \mathrm{C}$.

The SEM images in Figure 9(a,b) show the pore distribution with the highest concentration and larger ones near the center of the kernels. In Figure 9(c), the mosaic gives insight into a few features. First, there seems to be mostly high-density kernels, Figure 9(d) for example, with a smaller fraction exhibiting a central void that is $\sim 10 \%$ of the total volume of the kernel. An analysis of the sol-gel feedstock and the $\mathrm{UO}_{2}-\mathrm{UO}_{\mathrm{y}} \mathrm{C}_{1-\mathrm{y}}$ precursor is underway to determine whether or not they exhibit similar features. It is probable that these voids were created from so-called "lift out" that can occur with the back-potting technique of the mounting and polishing step used to prepare the samples for optical and SEM imaging. 

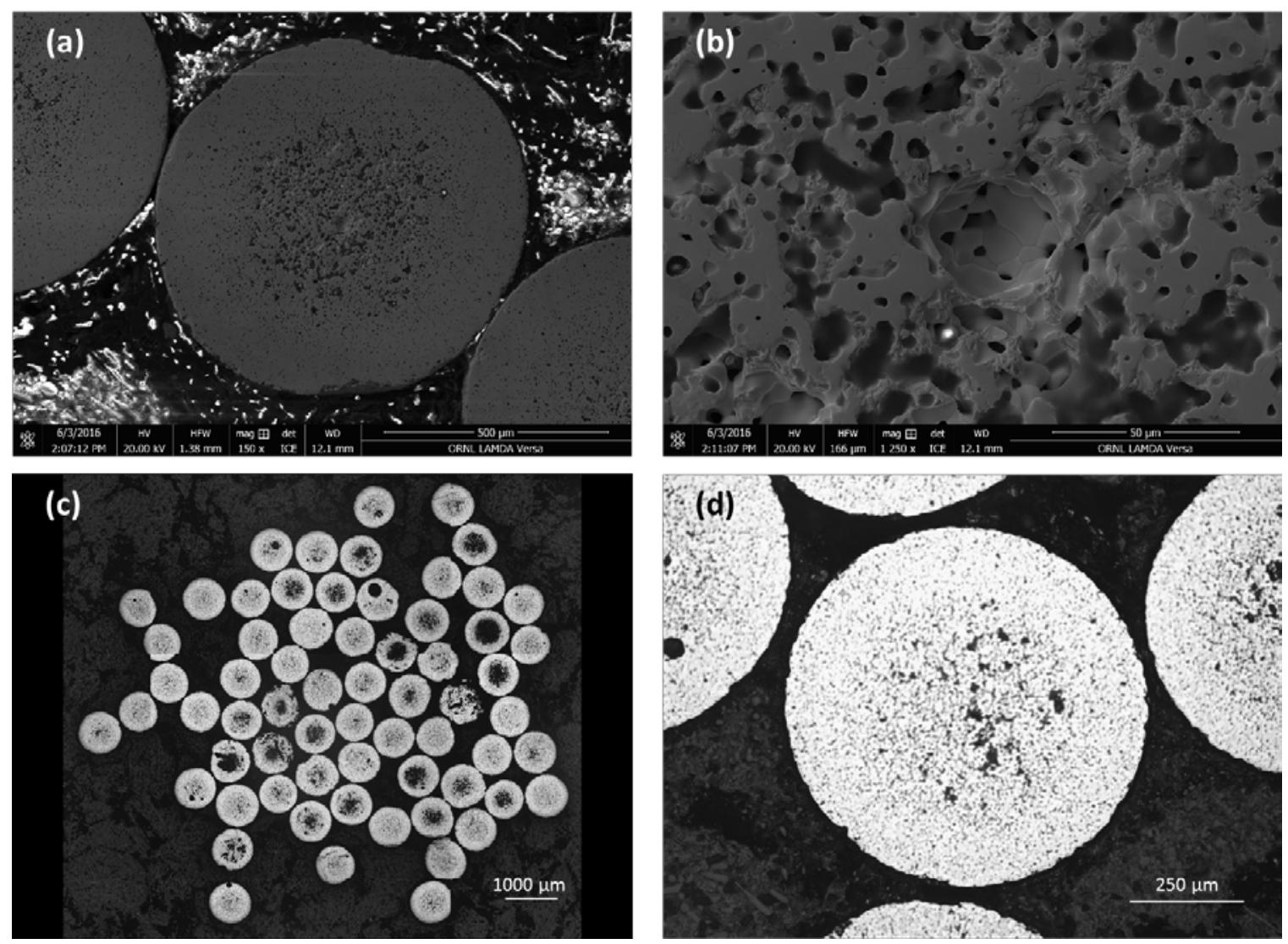

Figure 9. SEM images (a,b) showing the pore structure in a kernel from the final product $\mathrm{UC}_{0.27} \mathrm{~N}_{0.73}$. The optical microscope images in (c) and (d) show what appears to be mostly high density microspheres.

\section{CONCLUSIONS}

A 197.4-g batch of LEU-bearing, 800- $\mu$ m-diameter $\mathrm{UC}_{\mathrm{x}} \mathrm{N}_{1-\mathrm{x}}$ microspheres was produced using the optimized process determined in [3]. The XRD analysis showed the material to be phase-pure $\mathrm{UC}_{0.27} \mathrm{~N}_{0.73}$. The average density was determined to be $12.67 \pm 0.07 \mathrm{~g} / \mathrm{cm}^{3}$ or $89.9 \pm 0.5 \%$ TD for $\mathrm{UC}_{0.27} \mathrm{~N}_{0.73}$. This large batch of microspheres will be coated with TRISO layers using a CVD process developed at ORNL for irradiation testing that should aid qualification of UN as the kernel in TRISO particle fuel for the FCM design. 


\section{ACKNOWLEDGMENTS}

The authors are grateful to J.D. Hunn and M.P. Trammell at ORNL for valuable critiques and technical insight. The work presented in this paper was supported by the Advanced Fuels Campaign of the Fuel Cycle R\&D program in the Office of Nuclear Energy, US Department of Energy. 


\section{REFERENCES}

[1] K. A. Terrani, J. Kiggans, Y. Katoh, K. Shimoda, F. C. Montgomery, B. L. Armstrong, C. M. Parish, T. Hinoki, J. D. Hunn, L. L. Snead, J. Nucl. Mater., 426 (1) (2012) 268-76.

[2] K. A. Terrani, L. L. Snead, J. C. Gehin, J. Nucl. Mater., 427 (1) (2012) 209-24.

[3] T. B. Lindemer, C. M. Silva, J. J. Henry Jr, J. W. McMurray, B. C. Jolly, R. D. Hunt, K. A. Terrani, Carbothermic Synthesis of 820- $\mu$ m UN Kernels: Investigation of Process Variables, Oak Ridge National Laboratory (ORNL), Oak Ridge, TN (United States), Report ORNL/TM-2015/301 (2015)

[4] R. A. Lowden, Fabrication of Baseline and Variant Particle Fuel for AGR-1, Oak Ridge National Laboratory, Oak Ridge, TN, ORNL Report No. CF-06/02 (2006)

[5] D. A. Petti, J. T. Maki, J. D. Hunn, P. J. Pappano, C. M. Barnes, J. J. Saurwein, S. G. Nagley, J. M. Kendall, R. R. Hobbins, JOM, 62 (9) (2010) 62-6.

[6] J. A. Phillips, C. M. Barnes, J. D. Hunn, Proceedings of HTR 5th International Topical Meeting on High Temperature Reactor Technology, Prague, October 18-20, 2010 (2010)

[7] R. D. Hunt, T. B. Lindemer, M. Z. Hu, G. D. d. Cul, J. L. Collins, Radiochim. Acta, 95 (4) (2007) 225-32.

[8] C. M. Silva, T. B. Lindemer, S. R. Voit, R. D. Hunt, T. M. Besmann, K. A. Terrani, L. L. Snead, J. Nucl. Mater., 454 (1) (2014) 405-12.

[9] V. Bobkov, L. Fokin, E. Petrov, V. Popov, V. Rumiantsev, A. Savvatimsky, Thermophysical Properties of Materials for Nuclear Engineering: A Tutorial and Collection of Data, IAEA, Vienna, 2008. 